\title{
Biokinetics of americium and plutonium in the mussel Mytilus edulis
}

\author{
Poul Bjerregaard*, Sayhan Topçuoğlu**, Nicholas S. Fisher and Scott W. Fowler
}

International Laboratory of Marine Radioactivity, Musée Océanographique, MC-98000 Monaco

\begin{abstract}
Biokinetics in the mussel Mytilus edulis L. for americium and plutonium taken up from water and labelled diatoms Thalassiosira pseudonana were studied in a series of laboratory experiments. Mussels concentrated Am and Pu 10 to 50 times from both water and labelled diatoms in 5 d. Mussels retained between 1.5 and $16 \%$ of the Am ingested with labelled diatoms, the highest retention efficiency being reached for the lowest algal cell density tested. Retention efficiency for Am was about twice that for Pu. Pu kinetics in mussels fed Pu(III-IV) and Pu (V-VI) labelled diatoms were identical. Pu taken up from labelled diatoms was lost from soft parts at a slower rate than Am, resulting in decreasing $\mathrm{Am} / \mathrm{Pu}$ ratios in the soft parts during the depuration phase. Am taken up from labelled diatoms was principally contained in the visceral mass and excreted in feces. Uptake of Pu and Am over $24 \mathrm{~h}$ from water was proportional to the ambient concentration for shell, soft parts, and whole animal. After $5 \mathrm{~d}$ uptake from water the $\mathrm{Am} / \mathrm{Pu}$ ratio in soft parts was 1.5 times higher than in the ambient seawater; 20 to $30 \%$ of the Pu and 30 to $40 \%$ of the Am body burden was associated with the soft parts. Following uptake from water, loss from soft parts and shells proceeded at similar rates. Whole body elimination was faster for both elements after uptake from labelled diatoms than from water, and after simultaneous uptake by both routes, Pu was lost slightly faster than Am. After $75 \mathrm{~d}$ of loss the biological half-life in the most slowly exchanging compartment ranged from 73 to $108 \mathrm{~d}$ for both elements. Pu was lost from dead shells faster than Am, resulting in increasing $\mathrm{Am} / \mathrm{Pu}$ ratios during the loss phase. However, dissected shells from live mussels showed no increased Am/Pu ratio during the loss phase. Am and Pu leached from fecal pellets at rates ( $T_{b / 2}: 2$ to $3 \mathrm{w}$ ) which increased with temperature and salinity. The results show that uptake from water as well as from food will contribute to the mussels' Am and Pu body burden and that both routes of uptake could lead to the elevated Am/Pu ratios observed in soft parts of mussels contaminated in the natural environment.
\end{abstract}

\section{INTRODUCTION}

The use of mussels as sentinels of marine pollution has been explored for a variety of environmental contaminants, including the transuranic radionuclides plutonium and americium (Goldberg et al., 1978, 1983). Findings to date indicate that $\mathrm{Pu}$ and $\mathrm{Am}$, derived from atmospheric fallout and release from nuclear reprocessing plants, are detectable in Mytilus edulis, M. californianus, and M. galloprovincialis from many geographic regions (Goldberg et al., 1978, 1983; Hamilton and Clifton, 1980; Ballestra et al., 1982; Clifton et al., 1983). Generally, mussels collected in 1977 and 1978 from the West Coast of the United States had higher levels of $\mathrm{Pu}$ and Am and higher Am/Pu ratios in their soft parts than East Coast mussels (Goldberg et

\footnotetext{
- Present address: Institute of Biology, Odense University, Campusvej 55, DK-5230 Odense, Denmark

- Present address: Cekmece Nuclear Research Center, PO Box 1, Airport, Istanbul, Turkey
}

al., 1983) and elevated Am/Pu ratios in mussel soft parts relative to global fallout were found in $M$. galloprovincialis in the Mediterranean (Ballestra et al., 1982). Reasons for these regional differences are not certain, since complimentary data on dissolved and particulate radionuclide contents of the ambient seawater were not measured for all regions. Moreover, there is a paucity of information regarding the rates and routes of transuranic incorporation into mussels, although such data for other metals are now available (e.g. Phillips, 1980; Dahlgaard, 1981). Guary (1980) demonstrated that $M$. galloprovincialis is capable of concentrating Pu and Am directly from seawater; however, comparative uptake kinetics of $\mathrm{Pu}$ and/or Am from food $v s$. water have not been investigated thus far.

Koide et al. (1981) suggested on the basis of $\mathrm{Am} / \mathrm{Pu}$ ratios in seawater, particulates, and mussels that ingestion of contaminated particles represents the principal means of $\mathrm{Pu}$ and Am accumulation in mussels, while Hamilton and Clifton (1980) argued that 
water represents the more important source. This issue remains unsolved, yet knowledge about the uptake route is essential in interpreting field measurements.

It is also essential to assess the retention of transuranic radionuclides in the mussels if these animals are to be used effectively to monitor environmental fluctuations of these elements (Guary and Fowler, 1981). Guary and Fowler (1981) and Clifton et al. (1983) examined in situ depuration rates of plutonium and americium in experimentally contaminated and chronically contaminated (via effluent from a nuclear fuel reprocessing plant) mussels, respectively. Retention times appeared longer in the chronically contaminated animals, although again interpretation of the results is difficult due to lack of data on source terms and retention times in the different tissues (shell included).

Koide et al. (1982) proposed that bivalve shells, and possibly byssal threads, may prove more useful than soft parts of whole mussels as metal indicators since the former (particularly shell) are easier to handle, do not require prior depuration of mussels, and more accurately reflect ambient metal levels. Such a monitoring approach would require an understanding of metal retention times in shells. Only Guary and Fowler (1981) have measured depuration rates of $\mathrm{Pu}$ from shells (of dead mussels) and estimated Pu retention times, but no reports present a direct comparison of shell vs. soft parts retention for Pu or Am. Finally, no information exists on the retention of these radionuclides in bivalve fecal pellets, yet biodeposition by mussels and other bivalves may represent a significant mechanism by which these invertebrates influence the geochemistry of the transuranic elements in the nearshore coastal zone.

We have therefore conducted a series of laboratory experiments to examine various aspects of accumulation and retention of $\mathrm{Am}$ and $\mathrm{Pu}$ in mussels. We have investigated the water and food pathways as potential routes of transuranic uptake for mussels and compared subsequent transuranic tissue distributions. We have also measured retention of Pu (in 2 different oxidation states) and Am in double-labelled mussels, in which the source terms were well quantified. Finally, we measured retention of $\mathrm{Pu}$ and $\mathrm{Am}$ in experimentally produced fecal pellets under different temperature and salinity regimes.

\section{MATERIALS AND METHODS}

Organisms. Mussels Mytilus edulis L. from the coastal Mediterranean Sea were obtained commercially or from the field and used in all experiments. Prior to experimentation the mussels were cleaned of epifauna and -flora and acclimated in running seawater aquaria. All uptake experiments were conducted at $13^{\circ} \mathrm{C} \pm 1 \mathrm{C}^{\circ}$ and $38 \%$ salinity; in the depuration phase mussels were kept at $16{ }^{\circ} \mathrm{C} \pm 2 \mathrm{C}^{\circ}$. Wet weights of mussels changed less than $5 \%$ during the course of the experiments (Table 1).

Monocultures of the centric diatom Thalassiosira pseudonana (Clone $3 \mathrm{H}$ ) served as food in experiments assessing radionuclide assimilation from food. Cells were maintained as described by Fisher et al. (1983a). Labelled diatoms were prepared by adding ${ }^{241}$ Am (or ${ }^{241} \mathrm{Am}$ and ${ }^{237} \mathrm{Pu}$ in double-tracer experiment) to $\log$ phase cultures of $T$. pseudonana growing in $0.2 \mu \mathrm{m}$ filtered Mediterranean surface water enriched with $f / 2$ nutrients (Guillard and Ryther, 1962) minus the $\mathrm{Cu}, \mathrm{Zn}$, and EDTA additions. After $3 \mathrm{~d}$ growth, cells were removed from the labelled medium by $1 \mu \mathrm{m}$ Nuclepore filtration and resuspended ( $>95 \%$ efficiency) into $0.2 \mu \mathrm{m}$ Nuclepore filtered seawater. These cells were maintained in dim light for $24 \mathrm{~h}$ to allow for loss of loosely bound radionuclide (Fisher et al., 1983a) and then again filtered $(1 \mu \mathrm{m})$ and resuspended into $0.2 \mu \mathrm{m}$ filtered seawater. These suspensions of labelled diatoms were adjusted to the desired cell densities with $0.2 \mu \mathrm{m}$ filtered seawater, stored in the dark at $13^{\circ} \mathrm{C}$, and used as feeding suspensions for the mussels. Algal cell densities and partitioning of radionuclides between dissolved and particulate phases in the feeding suspensions were determined as in Fisher et al. (1983a).

Radioactive counting. The ${ }^{241} \mathrm{Am}$ was supplied by C. E. A., Gif-sur-Yvette, France; the ${ }^{237} \mathrm{Pu}$ by AERE, Harwell, UK. The $101 \mathrm{keV}$ and $60 \mathrm{keV}$ photons of ${ }^{237} \mathrm{Pu}$ and ${ }^{241} \mathrm{Am}$, respectively, were determined for all samples with a multichannel analyzer coupled to three $7.6 \mathrm{~cm}$ well-type $\mathrm{NaI}(\mathrm{Tl})$ crystals. Unless otherwise stated, counting times were sufficient to give propagated $1 \sigma$ counting errors of $<5 \%$. Mixed standards of appropriate ${ }^{241} \mathrm{Am}$ and ${ }^{237} \mathrm{Pu}$ concentrations were used to correct for some Compton addition from ${ }^{237} \mathrm{Pu}$ to the ${ }^{241} \mathrm{Am}$ peak and to account for physical decay of ${ }^{237} \mathrm{Pu}$ $\left(T_{1 / 2}=46 \mathrm{~d}\right)$.

\section{EXPERIMENTAL PROCEDURES}

Radionuclide uptake from seawater. Four separate experiments were conducted to examine Am and Am $+\mathrm{Pu}$ accumulation in mussels from filtered seawater.

In the first experiment accumulation of ${ }^{241} \mathrm{Am}$ from $0.2 \mu \mathrm{m}$ filtered seawater over a $5 \mathrm{~d}$ period was measured for 5 mussels kept in separate glass jars. During the $5 \mathrm{~d}$ period water was changed daily and the ${ }^{241} \mathrm{Am}$ concentration in aliquots of old and new media was determined. The ${ }^{241} \mathrm{Am}$ levels in the water column 


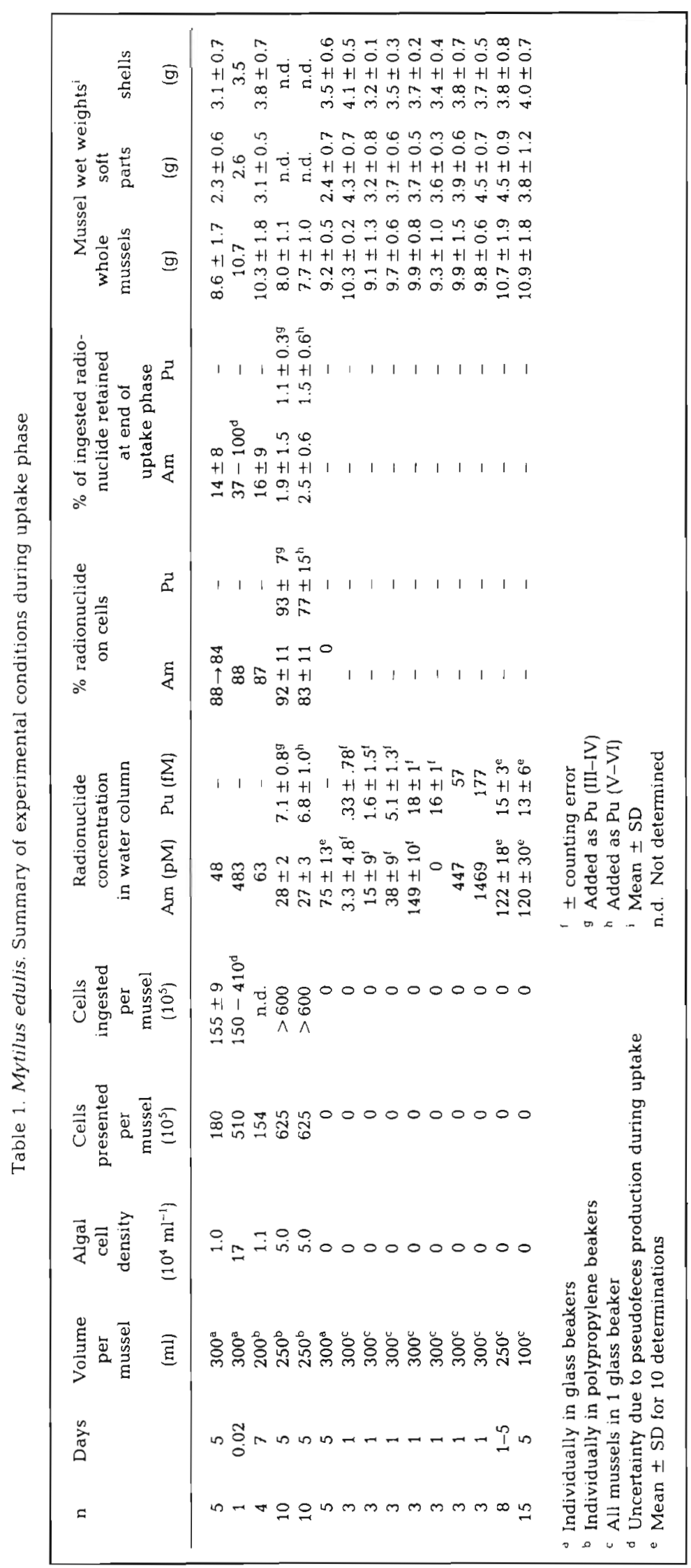


decreased in the $24 \mathrm{~h}$ intervals between water changes due to uptake by the mussels and adsorption on the glass walls (maximally 30 and $25 \%$, respectively, of the total ${ }^{241} \mathrm{Am}$ ). The mean concentration (used for all subsequent calculations) in the 5 jars during the exposure period was $75 \pm 13 \mathrm{pM} \mathrm{Am}(\mathrm{n}=50)$. The ${ }^{241} \mathrm{Am}$ content of the mussels was determined daily after a 5 min rinse in unlabelled seawater. After counting, the mussels were fed unlabelled diatoms for $1 \mathrm{~h}$ prior to submersion in fresh ${ }^{241} \mathrm{Am}$ labelled seawater. Following the uptake phase, the animals were allowed to depurate for $52 \mathrm{~d}$ in individual polypropylene beakers containing $250 \mathrm{ml}$ unlabelled seawater while their ${ }^{241} \mathrm{Am}$ content was monitored periodically. Water was changed daily and mussels were allowed to feed on unlabelled diatoms. After $52 \mathrm{~d}$, the mussels were dissected and the Am content of the tissues was deterInined.

In the second experiment 7 groups of 3 mussels were exposed to a range of ${ }^{237} \mathrm{Pu}$ and ${ }^{241} \mathrm{Am}$ concentrations (Table 1) in $0.2 \mu \mathrm{m}$ filtered seawater for $24 \mathrm{~h}$. Radionuclide contents in whole mussels, soft parts, and shells were determined.

In the third experiment 8 mussels were exposed to $122 \pm 18 \mathrm{pM}^{241} \mathrm{Am}$ together with $15 \pm 3 \mathrm{fM}{ }^{237} \mathrm{Pu}$ in $0.2 \mu \mathrm{m}$ filtered seawater. Water was changed daily and the radionuclide content of the mussels was determined. Two, 2, and 4 mussels were dissected on Days 1,3 , and 5, respectively, and the radionuclide content in soft parts and shells determined. Shells from the 4 mussels dissected on Day 5 were allowed to depurate in unlabelled seawater with the mussels from the following experiment.

In the last experiment 15 mussels were exposed to ${ }^{237} \mathrm{Pu}$ and ${ }^{241} \mathrm{Am}$ in $0.2 \mu \mathrm{m}$ filtered water for $5 \mathrm{~d}$ (Table 1) and uptake was monitored as in the previous experiment. After $5 \mathrm{~d}$ exposure mussels were allowed to depurate in unlabelled seawater - the first $6 \mathrm{~d}$ in a $4 \mathrm{l}$ glass jar with daily water changes, thereafter in running seawater aquaria. The radionuclide content of the mussels ( +4 shells) was determined periodically. Three, 3, 3, and 4 mussels were dissected on Days 11 , 41,54 , and 74 , respectively, and the radionuclide content in soft parts and shell determined. Two mussels died during the loss phase (at 21 and 32 d).

Radionuclide uptake from labelled diatoms. Retention of ${ }^{241} \mathrm{Am}$ and ${ }^{241} \mathrm{Am}+{ }^{237} \mathrm{Pu}$ from labelled diatoms was assessed in 3 separate and a single experiment, respectively.

In the first, 5 mussels in individual glass jars containing $300 \mathrm{ml}$ seawater were fed $10^{4}$ diatoms $\mathrm{ml}^{-1}$ for $5 \mathrm{~d}$. The total ${ }^{241} \mathrm{Am}$ concentration in the feeding suspension was $48 \mathrm{pM}, 88 \%$ of which was bound to cells, decreasing to $84 \%$ after $5 \mathrm{~d}$. The labelled feeding suspensions were changed and the ${ }^{241} \mathrm{Am}$ content in the rinsed mussels was determined at $4,18,44,69,80$, and $120 \mathrm{~h}$. Samples for determination of cell densities and partitioning of ${ }^{241} \mathrm{Am}$ between water and cells were taken from old and new feeding suspensions at each water change. After 5 d, mussels were transferred to unlabelled seawater and eventually dissected as described in the first water uptake experiment. Fecal pellets from 2 of the mussels were collected by pipet during the first $17 \mathrm{~d}$ of depuration, and their ${ }^{241} \mathrm{Am}$ content was determined.

In a similar experiment 4 mussels were fed labelled diatoms for $7 \mathrm{~d}$ (Table 1). To estimate the amount of ${ }^{241} \mathrm{Am}$ ingested with the diatoms, fecal pellets were collected for radioanalysis each day during the uptake phase. These mussels were dissected after $2 \mathrm{~d}$ depuration in unlabelled seawater.

Uptake of ${ }^{241} \mathrm{Am}$ from a dense diatom suspension during $30 \mathrm{~min}$ was examined in a third experiment (Table 1); only 1 of the 2 mussels employed opened the valves for filtration.

To examine uptake of ${ }^{241} \mathrm{Am}+{ }^{237} \mathrm{Pu}, 2$ batches of double-labelled diatoms were produced - one with ${ }^{241} \mathrm{Am}$ and ${ }^{237} \mathrm{Pu}$ (III-IV), the other with ${ }^{241} \mathrm{Am}$ and ${ }^{237} \mathrm{Pu}$ (V-VI). The ${ }^{237} \mathrm{Pu}$ oxidation state was adjusted as in Fowler et al. (1975). Twenty feeding suspensions - 10 of each group - were contained in individual polypropylene beakers each holding $250 \mathrm{ml}$ feeding suspension. The algal cell density in all feeding suspensions was adjusted at $5 \times 10^{4} \mathrm{ml}^{-1}$. The radionuclide content of the cells is given in Table 1 . Ten mussels were exposed to ${ }^{241} \mathrm{Am}-{ }^{237} \mathrm{Pu}$ (III-IV) diatoms and another 10 to ${ }^{241} \mathrm{Am}-{ }^{237} \mathrm{Pu}(\mathrm{V}-\mathrm{VI})$ diatoms for $5 \mathrm{~d}$. The radionuclide content of the rinsed mussels was determined and the feeding suspensions changed daily, Following uptake, mussels were allowed to depurate in unlabelled seawater. During the first $11 \mathrm{~d}$, mussels were kept individually in glass jars with daily water changes, and thereafter they were kept in running seawater aquaria. After $1,17,30,51$, and $72 \mathrm{~d}$ of depuration, 2 mussels from each group were dissected in order to determine the distribution of the incorporated radionuclides.

${ }^{241} \mathrm{Am}$ and ${ }^{237} \mathrm{Pu}$ retention in fecal pellets. To investigate retention of ${ }^{241} \mathrm{Am}$ and ${ }^{237} \mathrm{Pu}$ in fecal pellets, 2 groups of 3 mussels each were fed ${ }^{241} \mathrm{Am}-{ }^{237} \mathrm{Pu}$ (III-IV) or ${ }^{241} \mathrm{Am}-{ }^{237} \mathrm{Pu}(\mathrm{V}-\mathrm{VI})$-labelled diatoms $\left(5 \times 10^{4} \mathrm{ml}^{-1}\right)$ for $5 \mathrm{~h}$ and their fecal pellets collected by pipet. Pellets from both groups of mussels were counted for radioactivity and then radionuclide retention was followed in seawater at 5,13 and $22{ }^{\circ} \mathrm{C}$. Pellets labelled with ${ }^{241} \mathrm{Am}$ - ${ }^{237} \mathrm{Pu}$ (III-IV) were also allowed to depurate at $19 \%$ seawater to assess the effect of salinity on leaching rates. The seawater containing the pellets was changed every 1 to $2 \mathrm{~d}$, whenever the pellets were collected for radioanalysis. 


\section{RESULTS}

\section{Radionuclide uptake from water}

${ }^{241} \mathrm{Am}$ and ${ }^{237} \mathrm{Pu}$ uptake from seawater over $24 \mathrm{~h}$ was generally proportional to the ambient radionuclide concentrations (Fig. 1). Both elements concentrated in

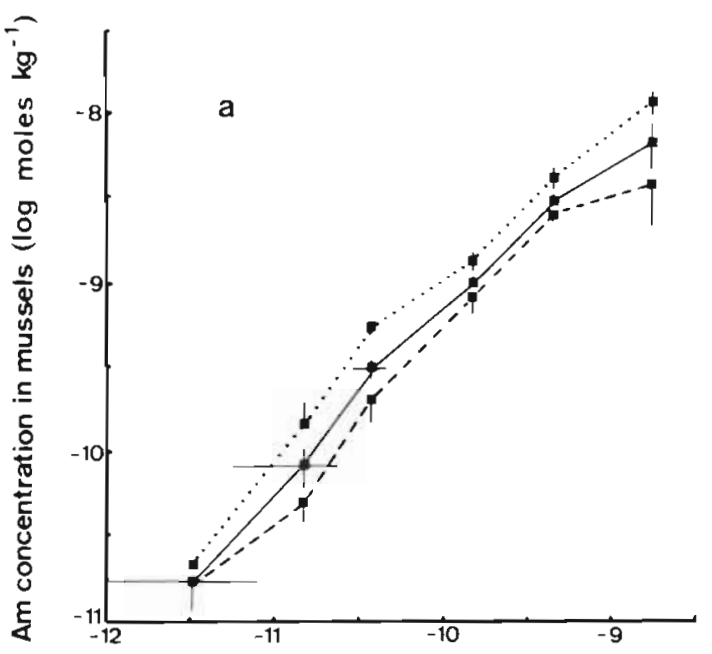

Am concentration in water $(\log \mathrm{MAm})$

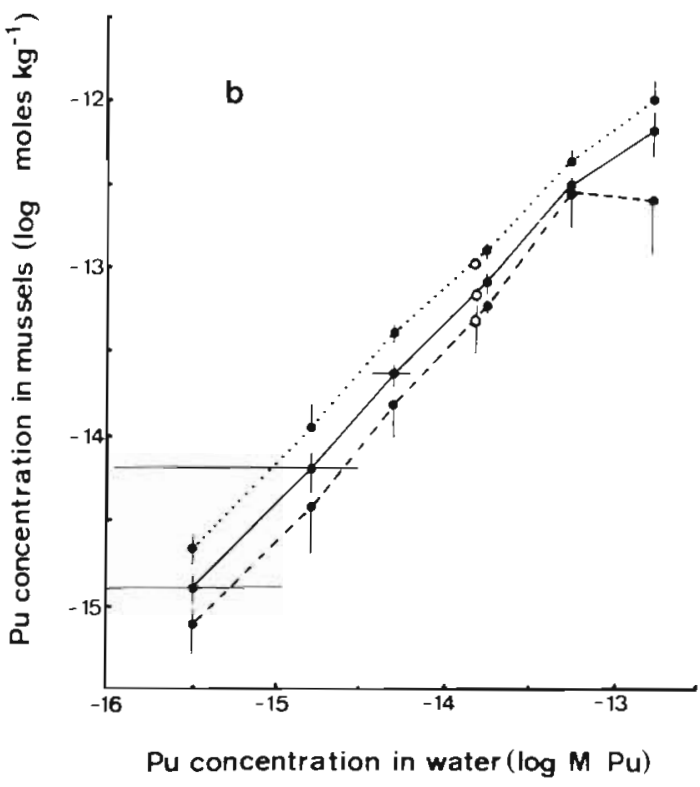

Fig. 1. Mytilus edulis. Uptake of ${ }^{241} \mathrm{Am}(\mathrm{a})$ and ${ }^{237} \mathrm{Pu}(\mathrm{b})$ in whole individuals ( - ), soft parts $(---)$, and shells $(\ldots)$ in mussels exposed to a range of ${ }^{237} \mathrm{Pu}$ and ${ }^{241} \mathrm{Am}$ concentrations in double-labelled seawater for $24 \mathrm{~h}$. Open symbols in (b) represent a group of mussels exposed to ${ }^{237} \mathrm{Pu}$ alone. Mean \pm SEM for 3 mussels in each group. Horizontal bars: counting errors on water samples

shells more than in soft parts. There was no influence of the ca. $10^{4}$ fold higher ${ }^{241} \mathrm{Am}$ concentration on the ${ }^{237} \mathrm{Pu}$ uptake (Fig. 1b). ${ }^{237} \mathrm{Pu}$ uptake from seawater
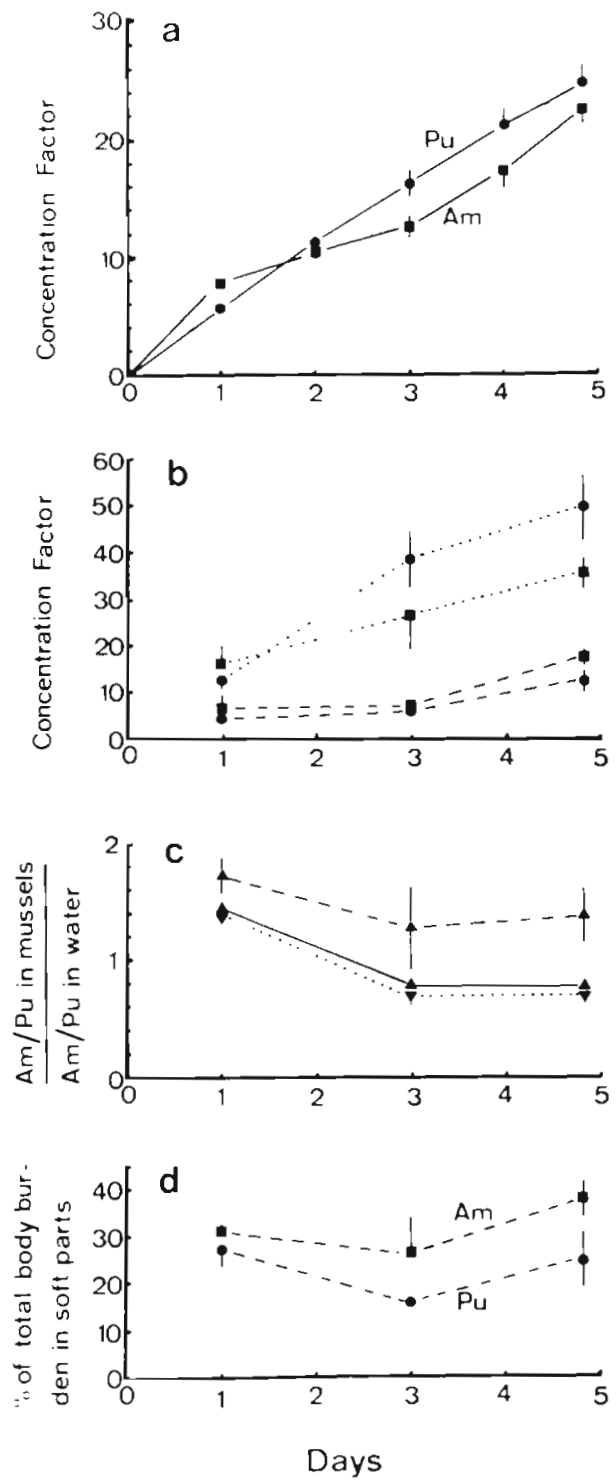

Fig. 2. Mytilus edulis. Uptake of ${ }^{241} \mathrm{Am}$ and ${ }^{237} \mathrm{Pu}$ in mussels exposed to ${ }^{241} \mathrm{Am}$ and ${ }^{237} \mathrm{Pu}$ in double-labelled seawater. : Ann; : Pu; (—) : whole animals; $(---)$ : soft parts; $(\ldots)$ : shells. Symbols represent mean \pm SEM for 2 or 4 mussels. (a) concentrations factors in whole individuals (the 4 mussels dissected on Day 5); (b) concentration factors in soft parts and shell; (c) Am/Pu ratio in mussels relative to $\mathrm{Am} / \mathrm{Pu}$ ratio in seawater; (d) \% of total body burden in soft parts. Two,2, and 4 mussels dissected on Days 1, 3, and 5, respectively

generally proceeded linearly over $5 \mathrm{~d}$ (Fig. 2 and 3), while ${ }^{241} \mathrm{Am}$ uptake showed different uptake patterns in the 3 experiments. Mussels held in 300 (Fig. 4a), 250 (Fig. 2), and 100 (Fig. 3) ml per mussel reached concentration factors (CF: mol radionuclide $\mathrm{g}^{-1}$ mussels wet wt. $\div$ mol total radionuclide $\mathrm{ml}^{-1}$ in medium) of ca. 30,23 , and 13, respectively, after $5 \mathrm{~d}$ exposure. The exposure volume affected $\mathrm{Pu}$ uptake less than Am uptake giving Pu CF's of 25 and 20 (5 d) for mussels held in 250 and $100 \mathrm{ml}$ per mussel. During the $24 \mathrm{~h}$ 


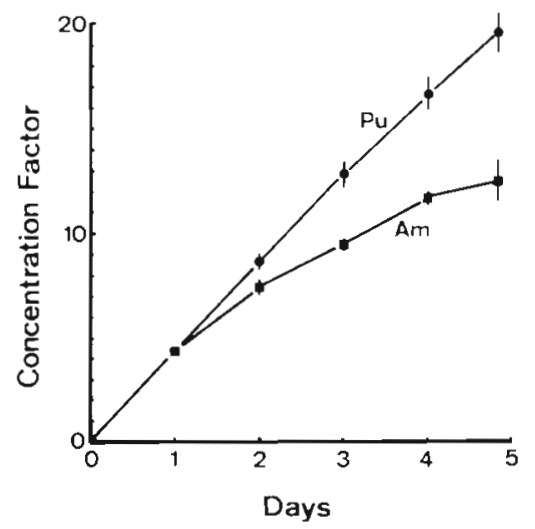

Fig. 3. Mytilus edulis. Uptake of ${ }^{241} \mathrm{Am}$ and ${ }^{237} \mathrm{Pu}$ in mussels exposed to ${ }^{241} \mathrm{Am}$ and ${ }^{237} \mathrm{Pu}$ in double-labelled seawater. Mean \pm SEM for 15 mussels

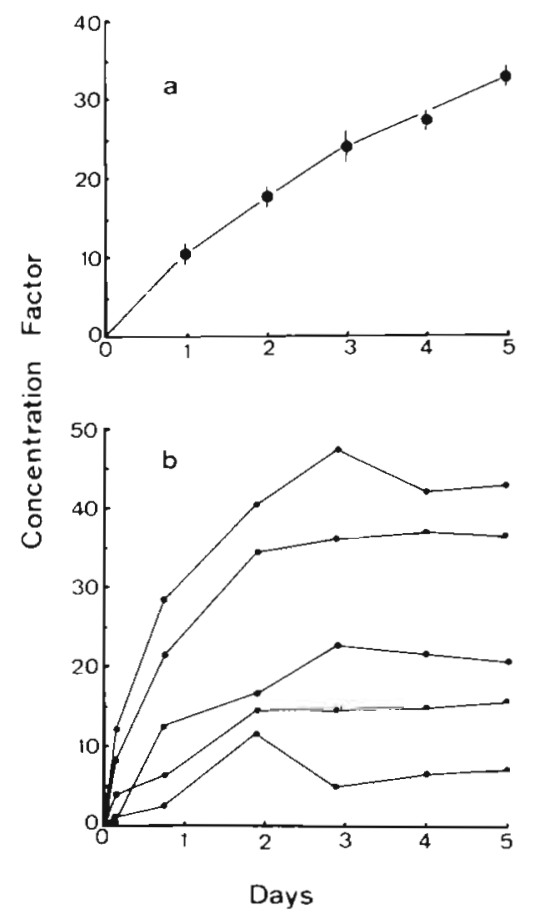

Fig. 4. Mytilus edulis. (a) Uptake of ${ }^{241} \mathrm{Am}$ in mussels exposed to ${ }^{241} \mathrm{Am}$ in seawater; mean \pm SEM for 5 mussels. (b) Uptake of ${ }^{241} \mathrm{Am}$ in mussels from ${ }^{241} \mathrm{Am}$ labelled diatoms; concentration factors for 5 individuals shown

between water changes the $\mathrm{pH}$ of the seawater declined (due to respiratory processes) from 7.9 to 7.3 and 7.0 , respectively, in the beakers containing 250 and $100 \mathrm{ml}$ per mussel. Differences in the $\mathrm{pH}$ or complexation with organic compounds released by the mussels may account for the different uptake in the 3 experiments.

Both $\mathrm{Am}$ and $\mathrm{Pu}$ were concentrated more by shell than soft parts during $5 \mathrm{~d}$ uptake from double-labelled seawater (Fig, 2b). Am, however, was accumulated more in soft parts than $\mathrm{Pu}$, giving elevated $\mathrm{Am} / \mathrm{Pu}$ ratios in the soft parts (Fig. 2c, d).

\section{Radionuclide uptake from labelled diatoms}

When ${ }^{241} \mathrm{Am}$ labelled diatoms $\left(10^{4}\right.$ cells $\left.\mathrm{ml}^{-1}\right)$ were the main ${ }^{241} \mathrm{Am}$ source (representing $>80 \%$ of the tota ${ }^{241} \mathrm{Am}$ in the water column), the CF increased for 2 to $3 \mathrm{~d}$, after which time it remained constant (Fig. $4 \mathrm{~b}$ and 5). The 5 mussels depicted in Fig. $4 \mathrm{~b}$ ingested almost identical amounts of labelled diatoms during uptake (Table 1), so differences in food (and ${ }^{241} \mathrm{Am}$ ) intake cannot account for the variation in CF's ( 7 to 43 ) reached by the individual mussels. The fraction of ingested ${ }^{241} \mathrm{Am}$ remaining in mussels at the end of the uptake phase was $14 \pm 8 \%$ in the $5 \mathrm{~d}$ experiment and $16 \pm 9 \%$ in the $7 \mathrm{~d}$ experiment (Table 1 ). The cumulative amount of ${ }^{241} \mathrm{Am}$ defecated increased linearly with time of feeding (Fig. 5).
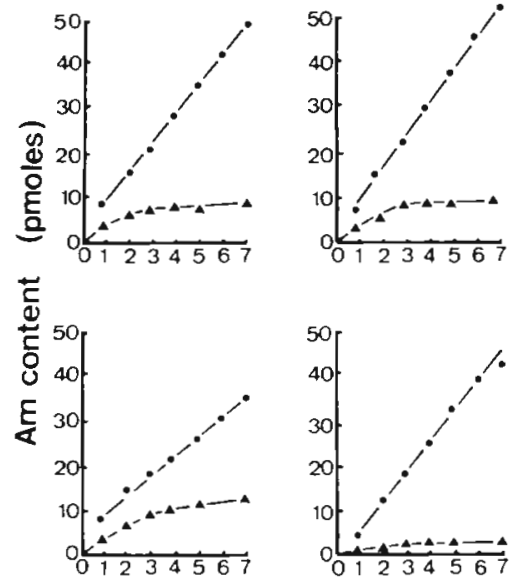

Days

Fig. 5. Mytilus edulis. ${ }^{241} \mathrm{Am}$ uptake from labelled diatoms in 4 mussels. ${ }^{241} \mathrm{Am}$ content in mussel; $\bullet$ cumulative amount of ${ }^{241}$ Am excreted via feces during the uptake phase

Kinetics of mussel uptake of ${ }^{241} \mathrm{Am}$ and ${ }^{237} \mathrm{Pu}$ from double-labelled diatoms are shown in Fig. 6 (see Table 1 for isotope partitioning in the feeding suspensions). After the first day uptake of both elements proceeded linearly and equilibria were not reached within $5 \mathrm{~d}$ feedings. No significant differences were observed between the $2{ }^{237} \mathrm{Pu}$ oxidation states, although partitioning in the media was somewhat different (Table 1). Concentration factors during the $5 \mathrm{~d}$ period for ${ }^{241} \mathrm{Am}$ were nearly double the ${ }^{237} \mathrm{Pu} C \mathrm{CF}^{\prime} \mathrm{s}: 1.79 \pm 0.10$ for ${ }^{241} \mathrm{Am}:{ }^{237} \mathrm{Pu}$ (III-IV) and $1.80 \pm 0.07$ for ${ }^{241} \mathrm{Am}$ : ${ }^{237} \mathrm{Pu}$ (V-VI). After uptake, each mussel contained an average of $3.2 \mathrm{pmol}^{241} \mathrm{Am}$ and $0.47 \mathrm{fmol}{ }^{237} \mathrm{Pu}$. Approximately $1.5 \%$ of the ingested ${ }^{241} \mathrm{Am}$ and $0.9 \%$ of the ${ }^{237} \mathrm{Pu}$ were retained by the mussels (Table 1 ). 


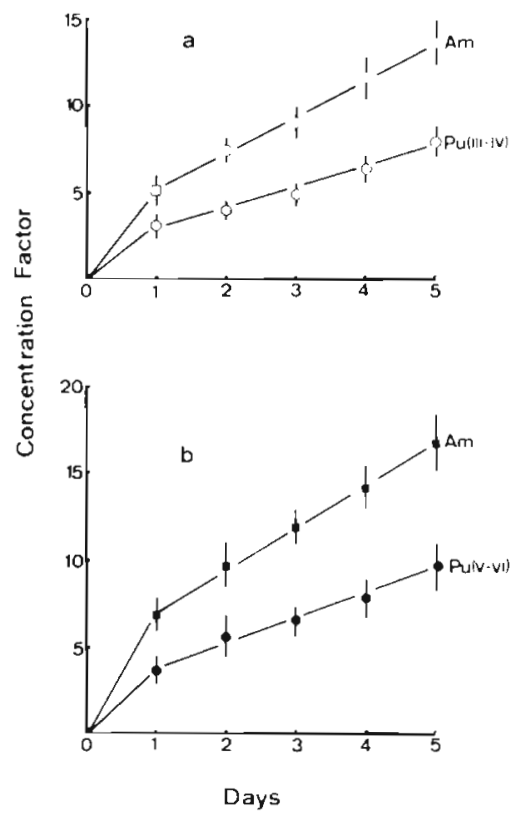

Fig. 6. Mytilus edulis. Uptake of ${ }^{241} \mathrm{Am}$ and ${ }^{237} \mathrm{Pu}$ from doublelabelled diatoms. (a) Diatoms exposed to ${ }^{241} \mathrm{Am}+{ }^{237} \mathrm{Pu}$ (III-IV); $\square{ }^{241} \mathrm{Am} ; O{ }^{237} \mathrm{Pu}$. (b) Diatoms exposed to ${ }^{241} \mathrm{Am}+$ ${ }^{237} \mathrm{Pu}(\mathrm{V}-\mathrm{VI}) ;{ }^{241} \mathrm{Am} ;{ }^{237} \mathrm{Pu}$. Each symbol represents mean \pm SEM for 10 mussels

\section{Loss of radionuclides}

Loss kinetics of ${ }^{241} \mathrm{Am}$ from mussels following accumulation from water and food are shown in Fig. 7. Multicompartment loss was evident and standard mathematical treatment of the data (Comar, 1955) was used to identify and evaluate the compartments. Biological half-lives $\left(\mathrm{T}_{\mathrm{b} / / 2}\right)$ and ${ }^{241} \mathrm{Am}$ content (as \% of the initial body burden) are given in Table 2 . Gener-

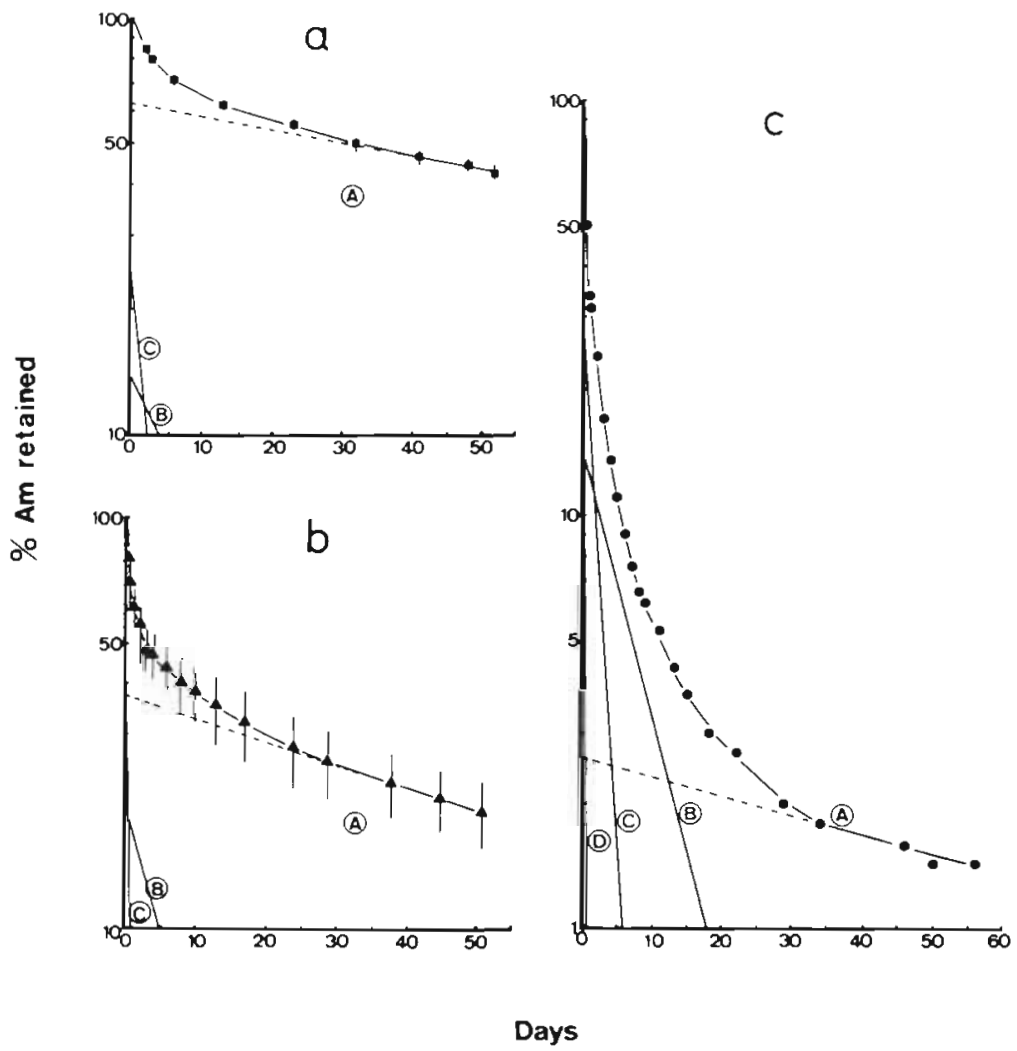

Fig. 7. Mytilus edulis. Loss of ${ }^{241}$ Am from mussels. (a) Loss after $5 \mathrm{~d}$ uptake from sea water; mean \pm SEM for 5 mussels. (b) Loss after 5 d uptake from labelled diatoms; mean \pm SEM for 4 mussels. (c) Loss after $30 \mathrm{~min}$ uptake from labelled diatoms; 1 mussel. Results from compartment analysis shown in Table 2

ally, ${ }^{241} \mathrm{Am}$ was lost more slowly following accumulation from seawater than from labelled food. Loss via defecation accounted for nearly all of the initial

Table 2. Mytilus edulis. Half-lives $\left(T_{\mathrm{b} y_{2}}\right.$ ) and radionuclide content (as $\%$ of the initial body burden) in compartments identified by mathematical treatment of loss curves (Fig. 7, 9 and 12)

\begin{tabular}{|c|c|c|c|c|c|c|c|c|c|c|}
\hline \multirow[t]{2}{*}{ Element } & \multicolumn{2}{|c|}{ Exposure } & \multicolumn{2}{|r|}{ A } & \multicolumn{2}{|r|}{$B$} & \multicolumn{2}{|r|}{ C } & \multicolumn{2}{|r|}{$\mathrm{D}$} \\
\hline & & & $\begin{array}{l}T_{b 1 / 2} \\
\text { (d) }\end{array}$ & $\begin{array}{c}\% \text { of body } \\
\text { burden }\end{array}$ & $\begin{array}{l}\mathrm{T}_{\mathrm{b}^{2 / 2}} \\
\text { (d) }\end{array}$ & $\begin{array}{l}\% \text { of body } \\
\text { burden }\end{array}$ & $\begin{array}{l}T_{b 1 / 2} \\
(h)\end{array}$ & $\begin{array}{l}\% \text { of body } \\
\text { burden }\end{array}$ & $\begin{array}{l}T_{b / 2} \\
(h)\end{array}$ & $\begin{array}{c}\% \text { of body } \\
\text { burden }\end{array}$ \\
\hline Am & Water & $5 \mathrm{~d}$ & 96 & 63 & 8.6 & 14 & 43 & 23 & & \\
\hline Am & Diatoms & $5 \mathrm{~d}$ & 55 & 37 & 5.2 & 20 & 12 & 43 & & \\
\hline $\mathrm{Am}$ & Diatoms & $1 / 2 \mathrm{~h}$ & 58 & 2.7 & 4.5 & 14 & 29 & 28 & 2 & 55 \\
\hline Am $\}$ & Diatoms & $5 d$ & 108 & 23 & 10.2 & 47 & 25 & 30 & & \\
\hline $\mathrm{Pu}\}$ & Dlatoms & $5 \mathrm{~d}$ & 73 & 23 & 14.5 & 49 & 17 & 28 & & \\
\hline $\mathrm{Am}$ \} & Water & $5 d$ & 97 & 61 & 12.0 & 12 & 72 & 27 & & \\
\hline $\mathrm{Pu}\}$ & Water & $3 a$ & 82 & 45 & 7.0 & 55 & & & & \\
\hline $\left.\mathrm{Am}^{\mathrm{d}}\right\}$ & Water & $5 d$ & 113 & 66 & 7.4 & 20 & 43 & 14 & & \\
\hline $\left.\mathrm{Pu}^{\mathrm{a}}\right\}$ & Praler & $5 a$ & 85 & 51 & 9.5 & 32 & 31 & 17 & & \\
\hline
\end{tabular}




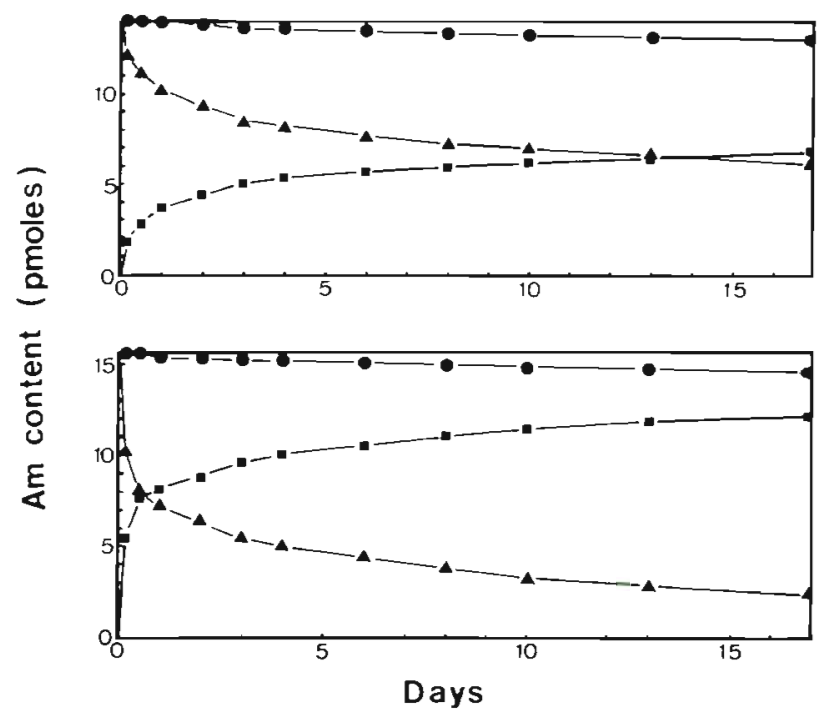

Fig. 8. Mytilus edulis. ${ }^{241}$ Am budget for 2 mussels during the initial loss phase after $5 \mathrm{~d}$ exposure to labelled diatoms. 4 ${ }^{241} \mathrm{Am}$ content of mussel; - cumulative amount of ${ }^{241} \mathrm{Am}$ excreted via feces; ${ }^{241} \mathrm{Am}$ content of mussel + cumulated amount of ${ }^{241} \mathrm{Am}$ excreted via feces decrease in ${ }^{241} \mathrm{Am}$ content of mussels fed labelled diatoms (Fig. 8). The small amount of ${ }^{241} \mathrm{Am}$ unaccounted for in the budgets can probably be attributed to loss from fecal pellets to water, and loss of soluble ${ }^{241} \mathrm{Am}$ (including ${ }^{241} \mathrm{Am}$ desorbed from shell) from the mussels. The mussels exposed to ${ }^{241} \mathrm{Am}$ labelled diatoms for $30 \mathrm{~min}$ lost the Am at a considerably faster rate than the mussels exposed for $5 \mathrm{~d}$. The rapid initial turnover of the element may be due to production of intestinal feces (Van Weel, 1961) which is known to occur at high cell densities. Most (72\%) of the ${ }^{241} \mathrm{Am}$ in mussels which accumulated dissolved radionuclide was associated with shell after 2 mo of depuration, whereas a higher fraction of the ${ }^{241}$ Am was found in the soft parts - principally visceral mass and mantle - after uptake by ingestion of labelled food (Table 3).

Loss of radionuclides taken up from ${ }^{241} \mathrm{Am}+$ ${ }^{237} \mathrm{Pu}(\mathrm{III}-\mathrm{IV})$ and ${ }^{241} \mathrm{Am}+{ }^{237} \mathrm{Pu}(\mathrm{V}-\mathrm{VI})$ labelled diatoms proceeded identically and pooled results from the 2 groups are presented in Fig. 9a, b. Loss of radionuclides taken up from double labelled water are shown in Fig. 9c, d. Distribution of ${ }^{241} \mathrm{Am}$ and ${ }^{237} \mathrm{Pu}$ in
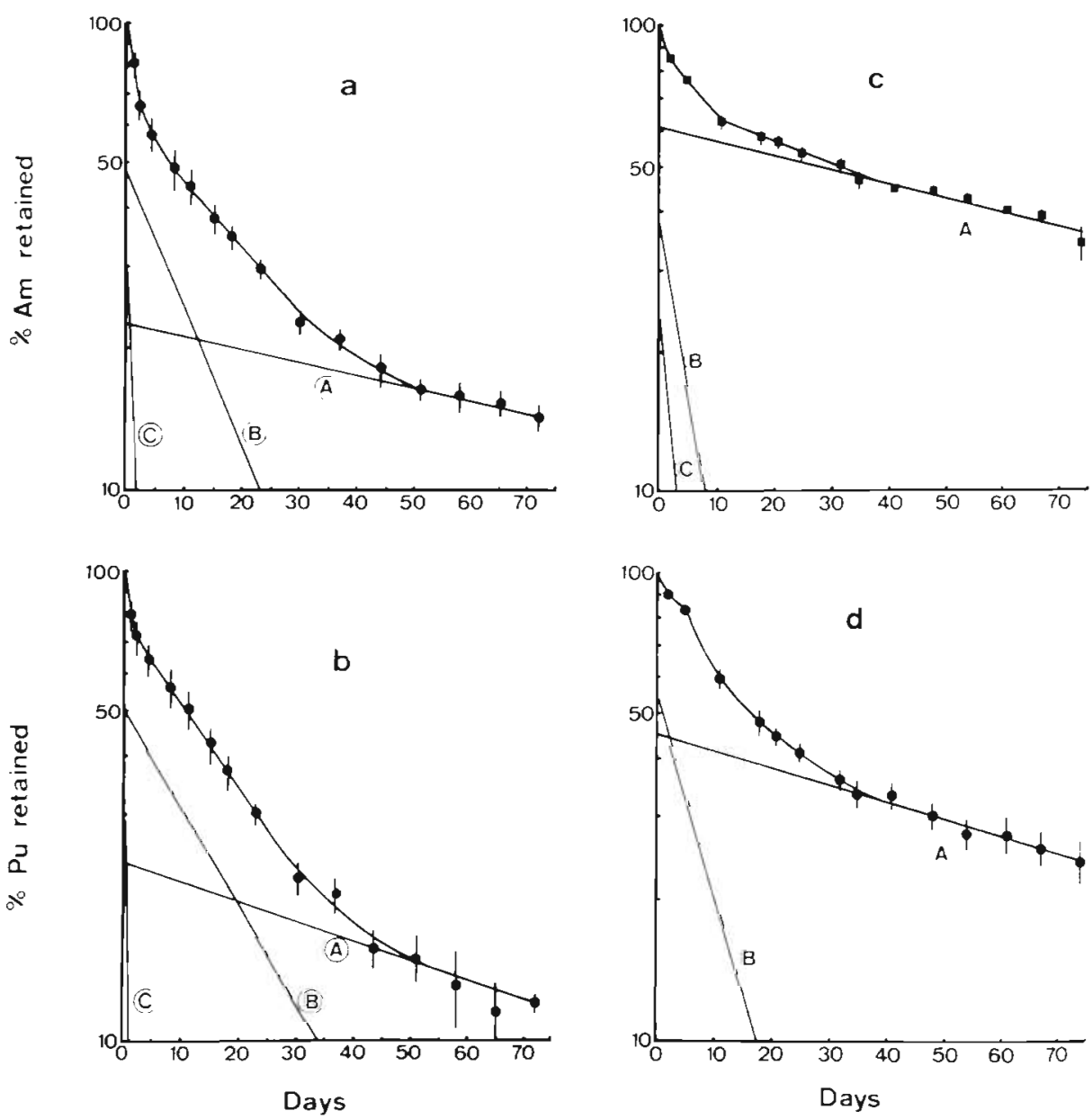

Fig. 9. Mytilus edulis. Loss of ${ }^{241} \mathrm{Am}$ (a), and ${ }^{237} \mathrm{Pu}$ (b), from mussels fed double-labelled diatoms. Mean \pm SEM for 4 mussels. Results from ${ }^{241} \mathrm{Am}$ ${ }^{237} \mathrm{Pu}$ (III-IV) and ${ }^{241} \mathrm{Am}-{ }^{237} \mathrm{Pu}$ (V-VI) mussels pooled. Loss of ${ }^{241} \mathrm{Am}$ (c) and ${ }^{237} \mathrm{Pu}(\mathrm{d})$ after uptake from double-labelled seawater. Mean \pm SEM for 15 to 4 mussels. Results from compartment analysis shown in Table 2 
Table 3. Mytilus edulis. Distribution of americium among organs at end of Am experiments

\begin{tabular}{|c|c|c|c|c|c|c|c|c|c|c|}
\hline \multirow{2}{*}{$\begin{array}{l}\text { Period } \\
\text { of } \\
\text { uptake }\end{array}$} & \multirow{2}{*}{$\begin{array}{l}\% \text { Am } \\
\text { on } \\
\text { cells }\end{array}$} & \multirow{2}{*}{$\begin{array}{c}\text { Number } \\
\text { of } \\
\text { mussels }\end{array}$} & \multirow{2}{*}{$\begin{array}{l}\text { Days } \\
\text { on } \\
\text { loss }\end{array}$} & \multirow{2}{*}{$\begin{array}{c}\% \text { of } \\
\text { initial } \\
\text { Am left }\end{array}$} & \multirow{2}{*}{$\begin{array}{c}\text { Am } \\
\text { left } \\
\text { (pmoles) }\end{array}$} & \multicolumn{5}{|c|}{$\%$ of body burden } \\
\hline & & & & & & gills & muscle & $\begin{array}{c}\text { visceral } \\
\text { mass }\end{array}$ & mantle & shell \\
\hline $5 \mathrm{~d}$ & $88-84$ & 1 & 24 & 51 & 3.8 & 2 & 2 & 71 & 8 & 21 \\
\hline $5 \mathrm{~d}$ & $88-84$ & 4 & 51 & $19 \pm 7$ & $1.7 \pm 1.0$ & $4 \pm 1$ & $5 \pm 2$ & $37 \pm 19$ & $15 \pm 8$ & $36 \pm 18$ \\
\hline $30 \mathrm{~min}$ & 88 & 1 & 56 & 1.5 & 0.62 & 8 & 0 & 23 & 53 & 16 \\
\hline $5 \mathrm{~d}$ & 0 & 5 & 52 & $43 \pm 4$ & $9.3 \pm 0.8$ & $3 \pm 1$ & $4 \pm 2$ & $4 \pm 2$ & $17 \pm 7$ & $72 \pm 7$ \\
\hline $7 \mathrm{~d}$ & 87 & 4 & 2 & $69 \pm 6$ & $5.7 \pm 2.7$ & $2 \pm 1$ & $2 \pm 1$ & $43 \pm 15$ & $11 \pm 6$ & $42 \pm 15$ \\
\hline
\end{tabular}
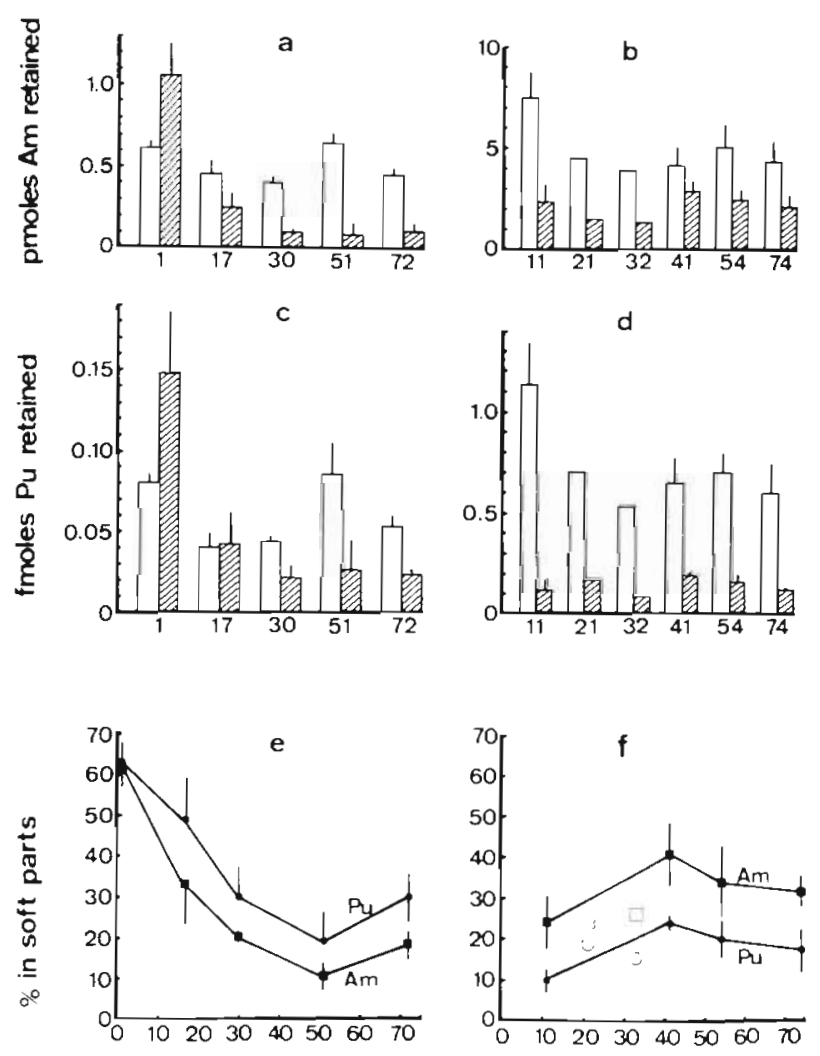

Days on loss

Fig. 10. Mytilus edulis. Distribution of ${ }^{243} \mathrm{Am}(\mathrm{a})$ and (b) and ${ }^{237} \mathrm{Pu}$ (c) and (d) between shells (open columns) and soft parts (hatched columns) in mussels dissected during loss phase after uptake from seawater (b), (d), (f), and labelled diatoms (a), (c), (e). Mean \pm SEM. Number of mussels shown in Fig 11 legend. Open symbols in $f$ represent 2 dead mussels

mussels dissected during the loss phase is shown in Fig. 10, and $\mathrm{Am} / \mathrm{Pu}$ ratios (relative to the $\mathrm{Am} / \mathrm{Pu}$ ratio in the water column during the uptake phase) in whole animals, shells, and soft parts are presented in Fig. 11.

${ }^{237} \mathrm{Pu}$ was lost from whole mussels slightly faster than ${ }^{241} \mathrm{Am}$ after uptake via both routes, and both radionuclides were lost faster after uptake from labelled diatoms. Following ingestion of labelled diatoms, both

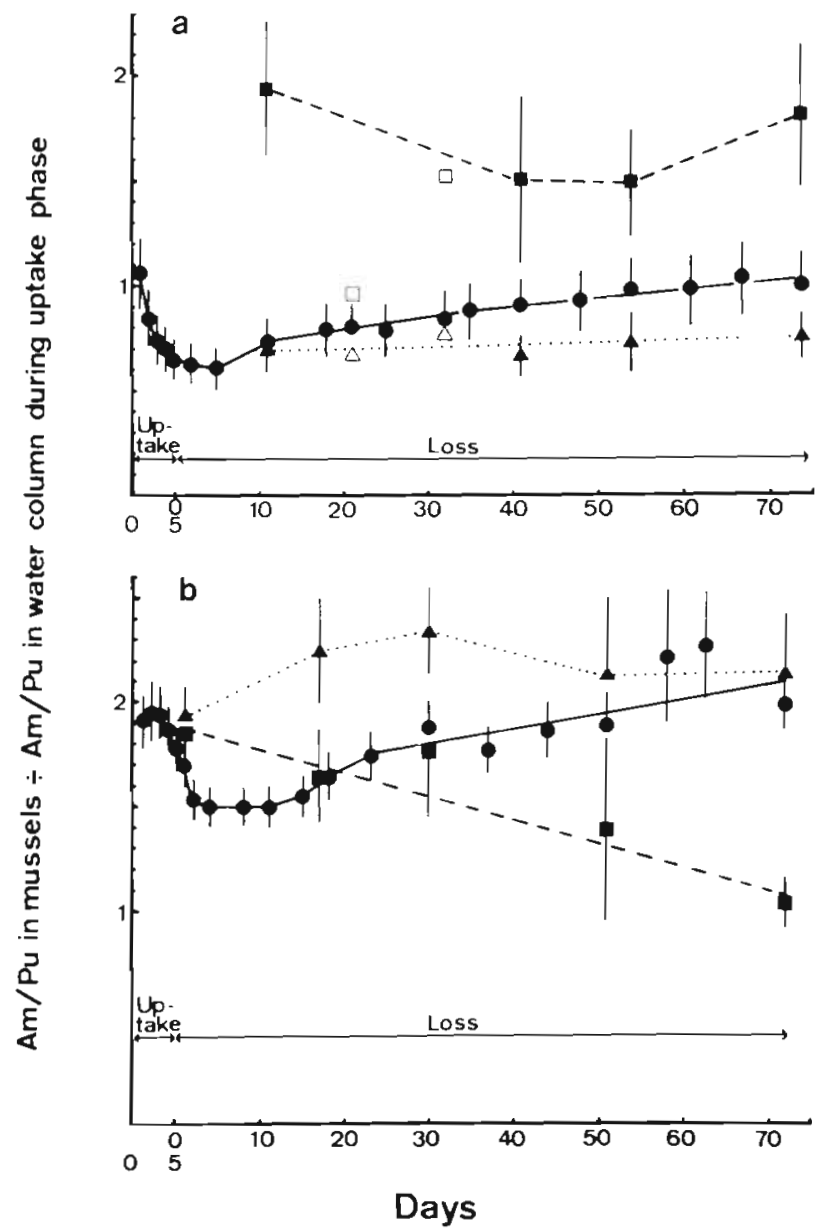

Fig. 11. Mytilus edulis. Am/Pu ratio in mussels relative to Am/Pu ratio in water column during uptake phase. (•) whole mussels; ( $\mathbf{a}$ ) soft parts; (4) shells. Symbols represent mean \pm SEM. (a) ${ }^{241}$ Am - ${ }^{237}$ Pu uptake from water; $15 \rightarrow 4$ mussels $(3,3$, 3 , and 4 dissected at Days 11, 41, 54 and 74, respectively); 2 mussels died at Days 21 and 32 (open symbols). (b) ${ }^{241} \mathrm{Am}-$ ${ }^{237} \mathrm{Pu}$ uptake from labelled diatoms; $20 \rightarrow 4$ mussels; 4 mussels dissected on Days 1, 17, 30, 51 and 72

radionuclides were lost from soft parts faster than from shells, while ${ }^{237} \mathrm{Pu}$ and ${ }^{241} \mathrm{Am}$ taken up from water were lost from soft parts and shells at similar rates (Table 2).

After ingestion of labelled diatoms the $\mathrm{Am} / \mathrm{Pu}$ ratio 

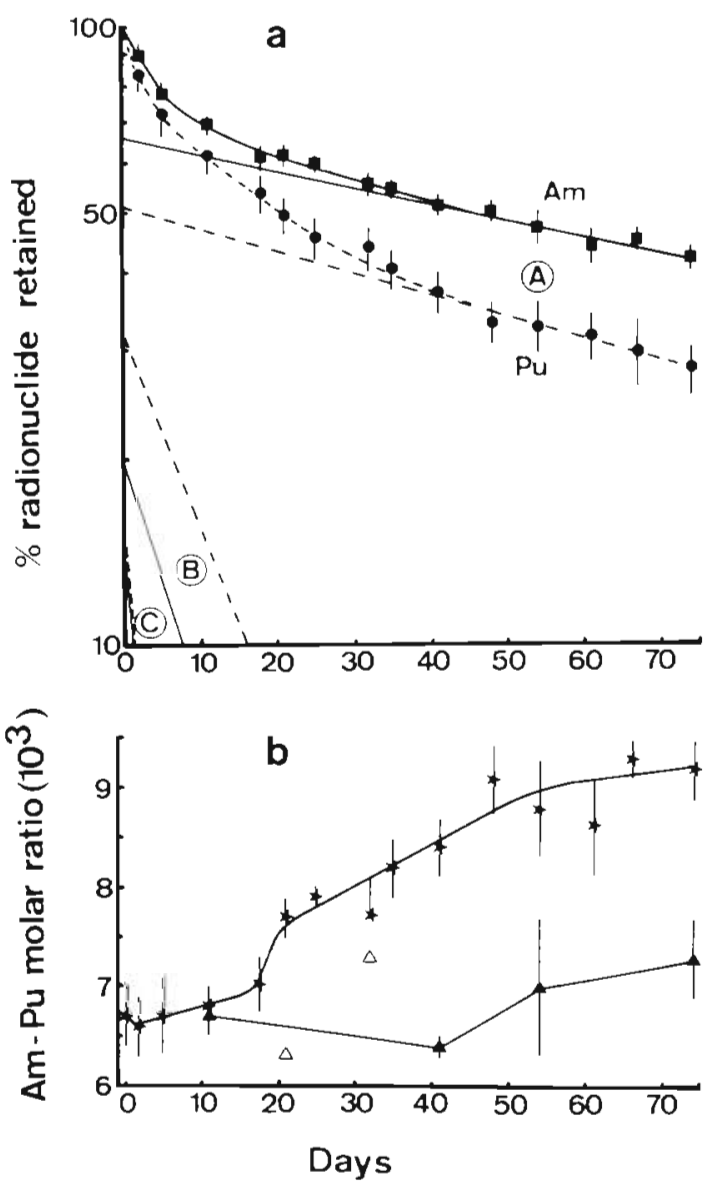

Fig. 12. Mytilus edulis. (a) Loss of ${ }^{241} \mathrm{Am}$ (E) and ${ }^{237} \mathrm{Pu}(\bullet)$ from shells dissected out after $5 \mathrm{~d}$ uptake from seawater. Mean \pm SEM for 4 shells; results from compartment analysis shown in Table 2. (b) Stars: Am/Pu ratio in shells from (a) i Triangles: $\mathrm{Am} / \mathrm{Pu}$ ratio in shells dissected out from live mussels during loss phase after $5 \mathrm{~d}$ uptake from seawater

in the soft parts decreased during the loss phase (Fig. $11 \mathrm{~b})$. The equation for the $\mathrm{Am} / \mathrm{Pu}$ molar ratio during the loss phase is: Am/Pu molar ratio $=7500-42 \mathrm{x}$ days on loss. The slope of the straight line is significantly less than zero $(\mathrm{P}<0.05)$. The $\mathrm{Am} / \mathrm{Pu}$ ratio in soft parts after uptake from water remained at a high level (Fig. 11 a). The relative $A m / P u$ ratio in shells is a factor of 2 to 3 higher after uptake from labelled diatoms than after accumulation from filtered water, and neither of the 2 ratios change significantly during loss phase (Fig. $11 \mathrm{a}, \mathrm{b})$

${ }^{237} \mathrm{Pu}$ was lost from 'dead shells' faster than ${ }^{241} \mathrm{Am}$ (Fig. 12; Table 2) giving increasing $\mathrm{Am} / \mathrm{Pu}$ ratios during the loss phase (Fig. 12b). Shells dissected from live mussels during the loss phase, however, showed no increased $\mathrm{Am} / \mathrm{Pu}$ ratio during the loss phase.

Loss of ${ }^{241} \mathrm{Am}$ and ${ }^{237} \mathrm{Pu}$ from labelled fecal pellets proceeded at identical rates, increasing with temperature and salinity (Fig. 13).

\section{DISCUSSION}

Results from the uptake experiments indicate that both water and ingested food can serve as sources of americium and plutonium for Mytilus edulis. Mussels retained 1 to $15 \%$ of the radionuclide ingested with labelled diatoms. This is comparable to the retention efficiency for Am from labelled diatoms in euphausiids (2 to $8 \%$; Fisher et al., 1983b), while the pelagic tunicate Oikopleura dioica retained $32 \%$.

The absorption efficiency for the organic content of ingested food increases with decreasing ingestion rate in Mytilus edulis (Bayne, 1976). This may be the reason why mussels fed $10^{4}$ and $5 \times 10^{4}$ cells $\mathrm{ml}^{-1}$ retained about 15 and $2 \%$ of ingested Am, respectively, and why the former mussels reached equilibrium within 2 to $3 \mathrm{~d}$ while the latter mussels did not. Borchardt (1983) similarly found an increased Cd-accumulation effi-
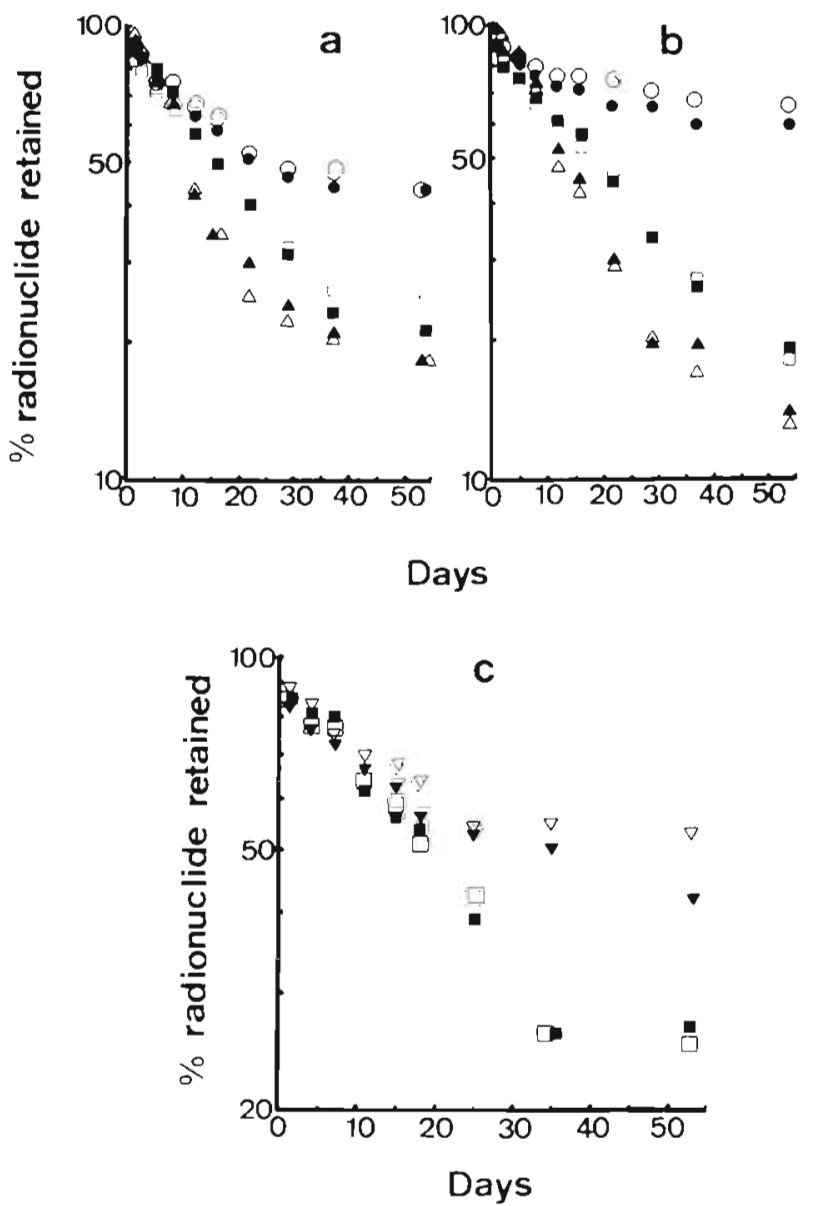

Fig. 13. Mytilus edulis. Loss of ${ }^{241} \mathrm{Am}$ and ${ }^{237} \mathrm{Pu}$ from fecal pellets excreted by mussels which ingested ${ }^{241} \mathrm{Am}-{ }^{237} \mathrm{Pu}-$ labelled diatoms. ${ }^{241} \mathrm{Am}, 5^{\circ} \mathrm{C}$ - ${ }^{241} \mathrm{Am}, 13^{\circ} \mathrm{C}$. ${ }^{241} \mathrm{Am}$, $22^{\circ} \mathrm{C} ;{ }^{237} \mathrm{Pu}, 5^{\circ} \mathrm{C} ; \square{ }^{237} \mathrm{Pu}, 13^{\circ} \mathrm{C} ; \triangle^{237} \mathrm{Pu}, 22^{\circ} \mathrm{C}$. (a) Diatoms exposed to ${ }^{241} \mathrm{Am}$ and ${ }^{237} \mathrm{Pu}$ (III-IV); (b) diatoms exposed to ${ }^{241} \mathrm{Am}$ and ${ }^{237} \mathrm{Pu}(\mathrm{V}-\mathrm{VI}) ;(c)$ salinity effects; $-{ }^{241} \mathrm{Am}, 38 \%$;

${ }^{241} \mathrm{Am}, 19 \% ; \square^{237} \mathrm{Pu}, 38 \% ; \nabla{ }^{237} \mathrm{Pu}, 19 \%$;iatoms labelled with ${ }^{241} \mathrm{Am}-{ }^{237} \mathrm{Pu}$ (III-IV) only; $13{ }^{\circ} \mathrm{C}$ 
ciency from Cd-labelled diatoms when the food assimilation efficency increased.

Plutonium was absorbed from food less efficiently than americium during 5 d uptake. Since equilibria were not reached for either element, the results may reflect different uptake rates only, rather than differences in equilibria CF's for the 2 elements. Americium and plutonium were presented on the same food source, at the same time, and to the same individual mussels, thus differences between the behavior of the 2 elements cannot be attributed to environmental or biological differences in the experimental conditions.

There were no significant differences between the reduced and oxidized $\mathrm{Pu}$, either in terms of uptake and retention by the diatoms, or availability to and retention in the mussels. Once associated with the diatoms, the Pu(V-VI) may of course be reduced to $\mathrm{Pu}(\mathrm{III}-\mathrm{IV})$, and thus no differences in behavior in the mussels would be expected. The failure to detect differences in behavior between the two oxidation states of $\mathrm{Pu}$ in our food chain experiments agrees with previous reports for accumulation in benthic worms (Fowler et al., 1975), phytoplankton (Fisher et al., 1983a), and sediments (Aston and Fowler, 1984).

Most of the americium and plutonium associated with the diatoms is bound to the cell surface (Fisher et al., 1980; Fisher et al., 1983d), and under laboratory conditions CF's for americium and plutonium in Thalassiosira pseudonana are almost identical (Fisher et al., 1983a, c). Transfer of these radionuclides from diatoms to mussels could take place either by desorption from the surface of the algae along the alimentary canal or by absorption of the elements through digestive processes in the digestive gland. Hamilton and Clifton (1980) concluded that the former of the two possible mechanisms of transfer was unlikely to take place. Food absorption in the digestive gland occurs mainly by phagocytosis (Bayne, 1976), and the elevated $\mathrm{Am} / \mathrm{Pu}$ ratio in the mussels after exposure to double-labelled diatoms show that these elements do not merely reflect atom ratios in the ingested food.

Uptake directly from water during a $5 \mathrm{~d}$ period produced elevated $\mathrm{Am} / \mathrm{Pu}$ ratios in the soft parts of the mussels, and the results of the 'water' and the 'food' uptake experiments are consistent with the hypothesis of Pentreath (1981) that americium is more biologically available than plutonium in many marine species.

In our experiments uptake of Am and Pu over $24 \mathrm{~h}$ were proportional to the ambient radionuclide concentration. That uptake in whole mussels, shell, or soft parts should reflect the ambient metal concentration is the basis of the entire 'Mussel Watch' concept (Goldberg et al., 1978, 1983). Shells generally showed the most regular response to ambient metal concentration. These findings are in accordance with Stureson's
(1978) and Nolan and Duke's (1983) results for cadmium in shell and indicate that shell is a good environmental monitor for transuranic elements (see Koide et al., 1982). The radionuclides detected in the shells in our study were probably adsorbed on the surface directly from the water. That reactive transuranic elements would adsorb to shell is entirely consistent with their behavior on other types of surfaces, including algal surfaces (Fisher et al., 1980; Fisher et al., 1983a), crustacean chitin surfaces (Fowler et al., 1975; Fisher et al., 1983b), mucopolysaccharide surfaces (Gorsky et al., 1984), and marine sediments (Aston and Fowler, 1984).

In the experiment where mussels were exposed to labelled diatoms the Am and Pu concentrations in the dissolved phase were proportional to the total Am and $\mathrm{Pu}$ concentrations. Thus, the differences in $\mathrm{Am} / \mathrm{Pu}$ ratios reached by the shells in the 2 experiments are probably real. In the 'food' uptake experiments the dissolved Am and Pu were released from the diatoms, perhaps complexed to algal exudates. The presence of excreted metabolites in the water reduces $\mathrm{Pu}$ uptake from water by the polychaete Nereis diversicolor (Fowler et al., 1975), and the high $\mathrm{Am} / \mathrm{Pu}$ ratio in the mussel shells in the 'food' uptake experiment may be explained by a reduced availability of the dissolved Pu.

The radionuclides accumulated from ingested diatoms and filtered water were retained by mussels for a longer period than has been observed in some other filter feeding invertebrates (Fisher et al., 1983b; Gorsky et al., 1984). It is emphasized that the absolute values of the retention times in mussels given in this report can be considered only as approximations for cases in which the exposure period is very short (in our case, $5 \mathrm{~d}$ ); the retention time in long-term exposed animals may be quite different (Guary and Fowler, 1981; Clifton et al., 1983). However, while the absolute $\mathrm{T}_{\mathrm{b} / \mathrm{z}}$ values may be pertinent only to acutely exposed mussels, the processes of uptake and retention of Am and $\mathrm{Pu}$ elucidated in our experiments should generally apply to natural systems. In our experiments, it is uncertain whether the radionuclides taken up from water and food were assimilated and metabolized or merely associated with internal and external surfaces or remaining on bits of ingested particles that had not been defecated. Miramand (1983) showed that Am, Pu and $\mathrm{Cm}$ were associated with the tubule walls of the digestive gland in some benthic invertebrates. But further studies are necessary to see if the transuranic elements (like $\mathrm{Cd}, \mathrm{Hg}$, and $\mathrm{Zn}$ ) are immobilized in the tubuli of the digestive gland in membrane bound vesicles which are ultimately defecated (Janssen and Scholz, 1979; George and Pirie, 1980). Present knowledge about the behavior of $\mathrm{Pu}$ and $\mathrm{Am}$ in biological 
systems does not explain why ingested Am is lost faster than ingested $\mathrm{Pu}$. It is also uncertain why $\mathrm{Am} / \mathrm{Pu}$ ratios in 'dead' and 'live' shells differ during the depuration phase.

Most of the Am (and probably also Pu) taken up from labelled diatoms is excreted in the feces. The retention half-times (on the order of 2 to $3 \mathrm{w}$; Fig. 13) of the radionuclides in the fecal pellets are somewhat greater than those measured in diatoms maintained at $18^{\circ} \mathrm{C}$ (10 to $12 \mathrm{~d}$ for $T$. pseudonana) (Fisher et al., 1983a); thus incorporation of phytoplankton-bound transuranic elements in fecal pellets can apparently enhance their retention in particulate material. In comparison, measured retention half-times for ${ }^{241} \mathrm{Am}$ in fecal pellets of appendicularians feeding on the same labelled food source were about 6 d (Gorsky et al., 1984) while those in euphausiid fecal pellets were 40 to $50 \mathrm{~d}$ (Fisher et al., 1983b); differences between fecal pellets likely reflect the degree of compaction of the pellets (Gorsky et al., 1984). Recent work has shown that the fecal pellets of bivalves are highly enriched in various heavy metals and suggests that these pellets are important in element cycling through detritivorous food chains (Brown, 1982). Likewise, fecal pellets contaminated with Am or $\mathrm{Pu}$ may serve as enriched sources of these radionuclides for coprophagous feeders. Considering the retention times of transuranics in fecal pellets and the large quantities of biodeposits produced by bivalves (Rhoads, 1974), it seems probable that mussels act as effective packagers and redistributers of transuranics in the coastal environment.

The present experiments do not clearly demonstrate which route of uptake - food or water - is the more important for Am and Pu, since CF's for both elements after $5 \mathrm{~d}$ uptake are comparable for both uptake routes. Nevertheless, the relatively low assimilation efficiency of transuranic elements ( 1 to $15 \%$ ) in mussels probably results in an increase in the relative importance of the water route. The fraction of americium and plutonium associated with particles in marine waters varies between 4 and $90 \%$, with levels $<30 \%$ being most commonly encountered (Holm et al., 1980). Both routes of uptake produce the elevated Am/Pu ratios in soft parts observed in nature (Goldberg et al., 1978, 1983; Ballestra et al., 1982; Koide et al., 1982). Variations in americium and plutonium concentrations and $\mathrm{Am} / \mathrm{Pu}$ ratios in Mytilus sp. (Goldberg et al., 1978, 1983; Ballestra et al., 1982; Koide et al., 1982) may then be explained by variations in one or several of the following factors: (1) total Am and Pu concentrations in the water column, (2) partitioning of the elements between particulate and dissolved phases, (3) particle load, (4) particle composition, (5) particle selection of mussels in a given area, and (6) retention efficiency for ingested $\mathrm{Am}$ and $\mathrm{Pu}$.
Extrapolating our experimental results to nature, we would speculate that the higher Am and Pu observed in west coast mussels relative to Gulf Coast oysters and east coast mussels in the USA (Goldberg et al., 1983) simply reflect higher levels of these elements in coastal waters off the west coast. Further the high ratio (around 4) of shell Pu or Am to soft part Pu or Am in both west and east coast mussels (Koide et al., 1982) is similar to our findings with mussels following radionuclide accumulation from water (Table 3 and Fig. 2), suggesting that most of the radionuclides in these Mussel Watch mussels were accumulated from the dissolved phase.

Acknowledgements. The International Laboratory of Marine Radioactivity operates under a tripartite agreement between the International Atomic Energy Agency, the Government of the Prinicipality of Monaco, and the Oceanographic Institute of Monaco. We thank J.-L. Teyssié and K. Steele for technical assistance.

\section{LITERATURE CITED}

Aston, S. R., Fowler, S. W. (1984). Experimental studies on the behaviour of long-lived radionuclides in relation to the deep-ocean disposal of nuclear wastes. In: Radioactive waste management, Vol. 5. International Atomic Energy Agency, Vienna, p. 339-354

Ballestra, S., Thein, M., Fukai, R. (1982). Distribution of Transuranic nuclides in Mediterranean ecosystems. VI J. Etud. Poll. 1982: 47-52

Bayne, B. L. (1976). Marine mussels: their ecology and physiology. Cambridge University Press, Cambridge

Borchardt, T. (1983). Influence of food quantity on the kinetics of cadmium uptake and loss via food and seawater in Mytilus edulis. Mar. Biol. 76: 67-76

Brown, S. L. (1982). Estuarine benthic invertebrate faeces: observations on decomposition and on aspects of chemical cycling. Ph. D. thesis, Universitiy of Wales

Clifton, R. J., Stevens, H. E., Hamilton, E. I. (1983). Concentration and depuration of some radionuclides present in a chronically exposed population of mussels (Mytilus edulis). Mar. Ecol. Prog. Ser. 11: 245-256

Comar, C. L. (1955). Radioisotopes in biology and agriculture; principles and practice. McGraw-Hill, New York

Dahlgaard, H. (1981). Bioindicators for monitoring radioactive pollution of the marine environment. RIS $\varnothing$ Rept. No. 443, Risø National Laboratory, Roskilde, Denmark

Fisher, N. S., Bjerregaard, P., Fowler, S. W. (1983a). Interactions of marine plankton with transuranic elements. I. Biokinetics of neptunium, plutonium, americium, and californium in phytoplankton. Limnol. Oceanogr. 28: $432-447$

Fisher, N. S., Bjerregaard, P., Fowler, S. W. (1983b). Interactions of marine plankton with transuranic elements. III. Biokinetics of americium in euphausiids. Mar. Biol. 75: $261-268$

Fisher, N. S., Bjerregaard, P., Huynh-Ngoc, L., Harvey, G. R. (1983c). Interactions of marine plankton with transuranic elements II. Influence of disolved organic compounds on americium and plutonium accumulation in a diatom. Mar Chem. 13: 45-56

Fisher, N. S., Burns, K. A., Cherry, R. D., Heyraud, M. (1983d). 
Accumulation and cellular distribution of ${ }^{241} \mathrm{Am},{ }^{210} \mathrm{Po}$, and ${ }^{210} \mathrm{~Pb}$ in two marine algae. Mar. Ecol. Prog. Ser. 11: 233-237

Fisher, N. S., Olson, B. L., Bowen, V. T. (1980). Plutonium uptake by marine phytoplankton in culture. Limnol. Oceanogr. 25: 823-839

Fowler, S. W., Heyraud, M., Beasley, T. M. (1975). Experimental studies on plutonium kinetics in marine biota. In: Impacts of nuclear releases into the aquatic environment. International Atomic Energy Agency, Vienna, p. 157-177.

George, S. G., Pirie, B. S. J. (1980). Metabolism of zinc in the mussel, Mytilus edulis (L.): a combined ultrastructural and biochemical study. J. mar. biol. Ass. U. K. 60: 575-590

Goldberg, E. D., Bowen, V. T., Farrington, J. W., Harvey, G. R., Martin, J. H., Parker, P. L., Risebrough, R. W., Robertson, W., Schneider, E., Gamble, E. (1978). The mussel watch. Environ. Conserv. 5: 101-125

Goldberg, E. D., Koide, M., Hodge, V., Flegal, A. R., Martin, J. H. (1983). U. S. mussel watch; 1977-1978 results on trace metals and radionuclides. Estuar. coast. Shelf Sci. 16: 69-93

Gorsky, G., Fisher, N. S. Fowier, S. W. (1984). Biogenic debris from the pelagic tunicate, Oikopleura dioica, and its role in the vertical transport of a transuranium element. Estuar. coast. Shelf Sci. 18: 13-23

Guary, J. C. (1980). Recherches sur les transferts et la fixation du plutonium, de l'americium et du neptunium dans le milieu marin. These de Doctorat d'Etat (Sciences), Univ. d'Aix-Marseille II

Guary, J. C., Fowler, S. W. (1981). Americium-241 and plutonium-237 turnover in mussels (Mytilus galloprovincialis) living in field enclosures. Estuar. coast. Shelf Sci. 12: $193-203$

Guillard, R. R. L., Ryther, J. H. (1962). Studies of marine planktonic diatoms I. Cyclotella nana Hustedt, and Detonula confervacea (Cleve) Gran. Can. J. Microbiol. 8: 229-238

Hamilton, E. I., Clifton, R. J. (1980). Concentration and dis- tribution of the transuranium radionuclides ${ }^{239}+{ }^{240} \mathrm{Pu}$ and ${ }^{241} \mathrm{Am}$ in Mytilus edulis, Fucus vesiculosus and surface sediment of Esk estuary. Mar. Ecol. Prog. Ser. 3: 267-277

Holm, E., Ballestra, S., Fukai, R., Beasley, T. M. (1980). Particulate plutonium and americium in Mediterranean surface waters. Oceanologica Acta 3: 157-160

Janssen, H. H., Scholz, N. (1979). Uptake and cellular distribution of cadmium in Mytilus edulis. Mar. Biol. 55 133-141

Koide, M., Williams, P. W., Goldberg, E. D. (1981). Am-241/ $\mathrm{Pu}-239+-240$ ratios in the marine environment. Mar. environ. Res. 5: 241-246

Koide, M., Lee, D. S., Goldberg, E. D. (1982). Metal and transuranic records in mussel shells, byssal threads and tissues. Estuar. coast. Shelf Sci. 15: 679-695

Miramand, P. (1983). Etudes de laboratoire et de terrain sur le comportement de l'americium, du curium et du plutonium chez les especes benthiques marines: transfert a partir de l'eau ou du sediment. These de Doctorat d'Etat (Sciences), Univ. de Nantes

Nolan, C. V., Duke, E. J. (1983). Cadmium accumulation and toxicity in Mytilus edulis: involvement of metallothioneins and heavymolecular weight protein. Aquat. Toxicol. 4: $153-163$

Pentreath, R. J. (1981). The biological availability to marine organisms of transuranium and other long-lived nuclides. In: Impacts of radionuclide releases into the marine environment. International Atomic Energy Agency, Vienna, p. 241-272

Phillips, D. J. H. (1980). Quantitative aquatic biological indicators. Appl. Science Publ., London

Rhoads, D. C. (1974). Organism-sediment relation on the muddy sea floor. Oceanogr. mar. Biol. A. Rev. 12: 263-300

Stureson, U. (1978). Cadmium enrichment in shells of Mytilus edulis. Ambio 7: 122-125

Van Weel, P. B. (1961). The comparative physiology of digestion in molluscs. Am. Zool. 1: 245-252

This paper was submitted to the editor; it was accepted for printing on September 30, 1984 